\title{
Implementation and Supervision Of Stakeholders-Based Education Marketing East Java Indonesia
}

\author{
Eko Sigit Purwanto ${ }^{1}$, Akhyak $^{2}$, Achmad Patoni ${ }^{3}$ Imam Junaris $^{4}$ \\ ${ }^{1}$ Research Scholar, STAI Diponegoro Tulungagung, Tulungagung, East Java, Indonesia. \\ ${ }^{234}$ Research Scholar, State Islamic Institute of Tulungagung, Tulungagung, East Java, \\ Indonesia \\ *Corresponding Author: \\ Email: sigitpurwantoahmad82@gmail.com
}

\begin{abstract}
.
Private schools must try to improve education marketing management in order to get more students that will later support learning activities in schools. Marketing management in this research is how to introduce educational products, invite and influence people to become consumers or service users in an educational institution. This study uses a qualitative approach that has a post positivistic or interpretive paradigm with the aim of understanding the phenomena that occur in the field. This type of research is multisite. The data collection in this study was carried out by means of participant observation, in-depth interviews and documentation. Furthermore, the researchers analyzed the data using two methods, i.e.: on-site data analysis and cross-site analysis using the Miles Huberman interactive model, known as reduction and presentation of data and drawing conclusions. The results of this study are: 1) implementation of stakeholder-based educational marketing management which is carried out by carrying out the placement tests, fulfilling qualifications and improving teacher professionalism, fulfilling facilities and infrastructure, providing opportunities for students to take extra-curricular activities, targeting output (students) who are in good attitudes, smart, healthy, accomplished, and competitive, conducts routine evaluations, assimilates with stakeholders, and achieves customer satisfaction. The optimistic attitude and deep love of the alumni can then be called market fanatics, coming out from market ideology, 2) integrated supervision by combining inherent supervision and follow-up plans. Both institutions strive to guard all plans to achieve perfect targets in terms of educational marketing by eliminating errors or zero defects.
\end{abstract}

Keywords: Implementation, Supervision, Stakeholders

\section{INTRODUCTION}

The globalization era has entered all lines of human activity. All aspects of life get the impact, including the world of education. The stronger impact of globalization on the world of education is competition in attracting students or users in choosing schools. The competition creates many problems between one school and another. Various methods are used by educational institutions to get new students because as we know that educational management can run well if the number of students and the student achievement are in a good rank.If private schools only rely on the number of students without good management, more and more private schools will be abandoned by their users and they will go to the better schools. This situation forces private schools to keep up to date in keeping up with the changes and developments of the 
times.Various ways are carried out by private schools starting from increasing available human resources, improving curriculum and infrastructure with the aim of attracting students' interest, so that they make choices to study in the schools. However, the cost factor is a serious problem in improving the quality of private schools. On the other hands, the existing costs are only supported by the educational fee or donations paid by students. Therefore, the number of students owned by the school will have an influence on education financing. So, as a breakthrough, educational marketing management is a necessity to get a number of new students and to introduce the advantages that schools have, which in turn can increase the number of students.

Marketing is a social and managerial process in which individuals and groups share needs and desires by creating, offering and exchanging something of value with one another (Asmani, 2015). The key component that can be used as material for analysis to understand the concept of educational marketing is the concept of the market.

Market is a place to have any transactions of various commodities produced by producers based on what the consumers need, want and expect. The marketing will not run well if it is not balanced with a good management as well. One unit of marketing management is something that cannot be separated in order to promote the service products owned by schools.

According to Kartajaya \& Sula (2006), the marketing mix is a tool for producers which consists of various elements of a marketing program that need to be considered, so that the implementation of the established marketing and positioning strategies can be successfully conducted. In the context of education, the marketing mix is very important and can be combined in such a way as to produce a strategy that can be used to win the competition. Researchers in marketing have made great progress in formulating and implementing a sales response model for the marketing mix. In the Journal of Marketing Research, Manchanda (2004) states: "Researchers in marketing have made a great deal of progress in formulating and applying sales response models to elements of the marketing mix".According to Goi (2009), the marketing mix concept also has two important benefits.

First, it is an important tool used to enable one to see that the marketing manager's job is, in a large part, a matter of trading off the benefits of one's competitive strengths in the marketing mix against the benefits of others. The second benefit of the marketing mix is that it helps to reveal another dimension of the marketing manager's job. All managers have to allocate available resources among various demands, and the marketing manager will in turn allocate these available resources among the various competitive devices of the 
marketing mix. In doing so, this will help to instill the marketing philosophy in the organization ".

One step of the school marketing process recommended by a research is implementing the marketing mix. The marketing mix in the realm of education is a means of controlling educational institutions to get the desired target appreciation. Ivy presented the model in terms of seven factors. Chung-Kai and Chia Hung conducted research on five elements, i.e.: people, promotion, price, place and product in educational institutions. From this research, the five elements have a positive impact on the loyalty of students' parents (Alipour, et al, 2012).

There are seven elements in the marketing mix, commonly abbreviated as $7 \mathrm{P}$, consisting of the traditional 4Ps used in the marketing of goods and the $3 \mathrm{Ps}$ as an expansion of the marketing mix. The 4P elements are product; what kind of services are offered, price; pricing strategy, place; where the service is provided, and promotion; how the promotion is done. While the $3 \mathrm{P}$ elements are people; quality and competence possessed by people involved in providing services, physical evidence; what kind of infrastructure is owned, and process; management of learning services provided (Alipour, et al, 2012).

Another fact that we can see in educational marketing which is a necessity in facing competition between educational institutions is the increasing number of educational institutions being abandoned by their customers (users), so that there are many mergers of several educational institutions (Hidayat \& Machali, 2010). Marketing is something that absolutely must be carried out by schools. Apart from being aimed at introducing, marketing in educational institutions serves to form a good image of the institution and attracts the interest of a number of prospective students (Muhaimin, et al, 2009). Without superior marketing, it is impossible to create a brand image of an institution. This consensus applies to all educational institutions, both general and Islamic educational institutions.

Islamic education institutions have an important role in improving the quality of education in an effort to carry out the goals of National Education. Various efforts have been made to improve the quality of education in Madrasah Tsanawiyah (MTs) and in Islamic Junior High School, one of which is to increase the input and output in learning (Hasyim, 2009). Efforts to improve the quality of education have been carried out by the government and elements of society with various forms of policies and activities even though the results have not been optimal (Maimun \& Fitri, 2010). The main role of Islamic education institutions is to produce generations who have the principles of faith and are knowledgeable. The hope of broad faith and knowledge is the birth of a superior and competitive civilization. The concept of science as one of the main assets of life and accompanied by belief and faith will be able to provide 
guidance to humans and become a balance in the personal life of every human being. Faith will lead people towards devotion and bring people to the point of truth in realizing the main goal of the development of science (Zubaedi, 2012).

In the advance era of technology and information, every business sector must be able to introduce the quality of its products, including educational institutions. They must be able to create quality products, because education is substantially a conscious and planned effort to achieve predetermined goals. From this process, the educational product is then marketed, so that it can be recognized well by the public.

Marketing management activities are needed by schools, so that the target of increasing new student admissions can be achieved. Marketing management is the activity of analyzing, planning, implementing, and supervising all programs, in order to obtain a favorable exchange rate with target buyers in order to achieve organizational goals (Alma, 2014).

If we look at educational institutions from a corporate perspective, then an educational institution is a production organization that produces educational services purchased by consumers. Its main consumers are students or university students and some other consumers. If producers are not able to market their products (educational services) because of the quality that consumers do not like, do not provide added value for individual personal improvement and the services provided are not satisfactory, the service products offered will not be sold out. As a result, schools will not have many students or there will be no enthusiasts and they may close (Alma \& Hurriyati, 2008). The existence of marketing science as we know today, actually provides opportunities for companies about what products have been produced, so that these products can be recognized and used by consumers.

The researcher took the theme "Implementation of Multi-site Study Stakeholder-based Educational Marketing Management in Islamic Junior High School of Sunan Gunung Jati, Ngunut, Tulungagung and Madrasah Tsanawiyah (MTs) Darul Hikmah Tawangsari Tulungagung", because of the motivation or the fact that basically Islamic educational institutions currently becomes one of alternatives and even then becomes the main choice of students in pursuing education in Islamic education institutions, and the consideration of the role of stakeholders in educational marketing. The key figures of stakeholders in educational marketing in private institutions are: 1) Principals; 2) School Committee; 3) Foundation; 4) Teacher; 5) Employees; 6) Society and 7) Alumni.Stakeholders in Islamic education are various parties who have a direct or indirect relationship with the success or failure of the ongoing educational process. These parties include principals, teachers, employees, foundations, committees, student guardians, alumni, government, leaders, and the society. In other words, when we talk about stakeholders, we are actually being required to be able to create an educational institution complete with all the systems, tools and attributes that can meet the expectations of society in general and parties with an interest in or related to education without abandoning the basic values of truth based on faith (Ulfatin \& Triwiyanto, 
2016).Stakeholders have two meanings, the first is someone who is fully trusted. The second one is people who are involved or influenced by an action. Stakeholders in the realm of education are those in charge in the school community, which are elements of the school, if one of these elements is absent, the learning process will be disrupted. This definition is further clarified in the Quality Management dictionary, stakeholders are groups or individuals inside or outside the organization that influence and are influenced by the achievement of the mission, goals and strategies of the organization which usually consists of shareholders, employees, customers, government and its regulations (Ulfatin \& Triwiyanto, 2016).

Stakeholders are holders of all the interests. Individuals or certain groups who have any interest in an object are called stakeholders. So, education stakeholders can be interpreted as people who are both holders and providers of support to education or educational institutions. In other words, stakeholders are people or bodies with direct or indirect interest in educational activities in schools (Muhaimin, 2010).

The selection of the two research locations is based on the similarity that both are institutions within the Islamic boarding school, even though the characters of the two are different (Islam Junior High School of Gunung Jati, Ngunut, is in Salafiyah vision, while MTs Darul Hikmah Tawangsari is a Modern Islamic boarding school). In addition, there are interesting things that the researchers found related to the acquisition of students where the majority of students from the two educational institutions above were relatives, neighbors, or relatives of students who had previously studied at the two institutions. So, it seems that both educational institutions have branches spread across various places, which not only introduce the institution's products and services, but also serve as marketing institutions.

The alumni volunteered to invite, introduce, and influence their family, environment, and their relatives who have children entering junior high school, to continue their studies and also stay in these two institutions. Alumni are aware that the greatness of an institution is also measured by the size of the alumni's role which is manifested in their participation in registering new prospective students as well as a form of alumni's love for their school. From the two things that alumni have done both as marketing and as an effort to raise the name of their campus, it can be concluded that the alumni from Islamic Junior High School of Sunan Gunung Jati and MTs Darul Hikmah, are able to become walking models or product displays that present their respective institutions. Apart from what the alumni did, it turns out that the majority of the student guardians have the reason that educational institutions within the Islamic boarding school are an option for those who really want their children to master the typical religious knowledge of Islamic boarding schools guided by direct moral exemplary from the teacher (Kyai) plus the habit of congregating five time, reciting books, praying dhuha, praying qiyamul lail, regular study, and also still getting general knowledge through formal educational institutions within the boarding school. 


\section{METHODS}

This study used a qualitative approach (Moleong, 2004) and the type of research used was a multisite study. Direct data sources can be collected with natural settings. The focus of this research is to thoroughly analyze and find out the implementation and supervision of stakeholder-based marketing in improving the quality of student input at Islamic Junior High School of Sunan Gunung Jati, Ngunut and MTS Darul Hikmah Tawangsari, Tulungagung. Apart from substantive findings, formal findings or thesis statements are also the focus of this study.

Data collection techniques are carried out in the following ways: 1) Participant observation. Observation is a method used by researchers to obtain information directly about stakeholder-based marketing management that can increase the number of students at Islamic Junior High School of Sunan Gunung Jati, Ngunut, Tulungagung and MTs Darul Hikmah Tawangsari. In this observation, the researcher is involved with the daily activities of the object being observed or that is used as a source of research data. 2) In-depth interviews (in-depth interviews). Interviews were conducted by researchers to obtain information about stakeholder-based marketing management that can increase the number of students at Islamic Junior High School Sunan Gunung Jati, Ngunut, Tulungagung and MTs Darul Hikmah Tawangsari, Tulungagung. Interviews were conducted with principals, teachers, student employees, society and other sources. 3) Documentation (documentation). Documents are records of past events. Documents can be in the form of writings, pictures, or monumental works of a person. Utilization of documents includes; formulation of the vision and mission of the school, school work programs, inventory lists, government policy documents, monthly reports, school profiles, employee data, teaching assignments, educational calendars, student manuals, student council management and school committee memberships.

There are three stages in conducting data analysis, i.e.; (1). Data reduction; (2). Display data; (3). Conclusing drawing or data verification (Sugiyono, 2006).

\section{RESULT AND DISCUSSION \\ Stakeholders-Based Educational Marketing Implementation}

The dissertation with the title "Implementation of Stakeholder-Based Education Marketing Management", focuses on research questions related to the implementation of stakeholder-based education marketing. As Soewarji's opinion, actuating is an activity to encourage all group members to work consciously and voluntarily in order to achieve a predetermined goal in accordance with organizational planning and patterns. Implementation problems are basically closely related to the human element, so that its success is also determined by the leader's ability to deal with employees and employees. Therefore, it requires management skills in communication, high creativity and initiative that can encourage the morale of staffs and employees (Lazaruth, 1994). 
Each institution will certainly target students as the output who have good morality, smart, healthy, achievers, competitive and religious. Even though there are some who are pessimistic that everything can be realized or not, all institutions want to be the best. In the course of the process, the objectives of the institution are realized through a concrete and structured planning, process, evaluation and follow-up scheme.

The implementation of educational marketing at Islamic Junior High School of Sunan Gunung Jati is to oversee all the plans that have been compiled and set, so that the targets and goals set can also be achieved. The activities carried out include, the first one is carrying out an entrance test for prospective new students which is a form of implementation of student input planning that has become an activity program. The second is to fulfill the qualifications of teaching staff and increase the professionalism of teachers through teacher working groups and participation in training from the education office. The third is the fulfillment of learning facilities and infrastructure such as laboratories, libraries and classrooms that are comfortable, safe, and support a learning atmosphere. The fourth is to provide opportunities for students to take part in literacy activities, learn multimedia and the art of decoration as a form of implementing process planning and facilities for students' soft skills in order to target smart outputs, such as good character and competitivness through orderly rules and obligations as output of management planning. And the fifth is to carry out monitoring and mentoring at each activity, promote a cooperation with stakeholders, maximize the role of alumni, make an expeditions out of Java with alumni and hold any grand try outs.

All planning, which is an activity program, is sorted from the start to be delegated into divided work group duties and responsibilities. After it is clear who the person in charge is, then a schedule and time for the implementation of the activities of each working group is drawn up. Thus, the number of activities conducted will not collide with other activities. In addition, the distribution of responsibilities remains evenly distributed among all working groups that have been formed.

There are no obstacles regarding the location of the activity. Islamic Junior High School of Sunan Gunung Jati educational institution has carried out expedition activities outside Java with the alumni. The entire series and route of travel to market educational products have been prepared by alumni outside of Java island. The alumni said that this activity was a means of meeting the fellow alumni, especially those who live outside Java island. Sometimes creative ideas emerge after expeditions. For example, by looking at the vast geographic landscape outside Java island, an idea arises about what if there will be cooperation to develop Islamic boarding schools and educational institutions. These things are recorded and reported in a joint evaluation between the working group and the institution of Islamic Junior High School of Sunan Gunung Jati.

Carrying out placement tests for prospective students as a form of consistency in planning which is the initial capital to determine the next managerial and 
administrative steps. With this initial test, minimum qualifications and standards can be applied in order to get the number of students that match the expectations and targets of the institution. Fulfilling teacher qualifications and increasing teacher professionalism through comparative studies and training or education are steps in carrying out managerial education marketing. Based on the awareness that the changes and demands of the times are growing rapidly, the quality of teachers is an urgent matter to be improved and is always supported by knowledge that is relevant to change.The institution fulfills learning facilities and infrastructure such as laboratories and libraries, in an effort to create a comfortable, adequate, and safe learning environment for families studying at Sunan Gunung Jati Islamic Junior High School. Thus, students, teachers and alumni feel comfortable and proud of their campus. Schools provide opportunities for students to take part in extra-curricular activities in the form of scouting, literacy, sports, and decoration, which are soft skills development that will support students in the future. Mastery of soft skills is very important because it does not rule out a lot of potential that can be extracted from various activities outside of formal learning.

Routine evaluation or monitoring is a strategy in realizing the effectiveness of activities and efficiency in financing as well as accelerating response in realizing the targets planned. A program will run better if at the time of its implementation there is also monitoring which simultaneously carries out an evaluation function. The mingling with stakeholders is an effort to bring educational products closer to customers. All efforts to implement educational marketing are for the sake of realizing customer satisfaction by minimizing the risk of failure.

The implementations of stakeholder-based education marketing carried out by MTs Darul Hikmah Tawangsari, Tulungagung are; 1). carrying out the placement test as a form of implementation of student input planning, 2). conducting the fulfillment of teacher qualifications through comparative studies, 3). meeting the learning facilities and infrastructure, 4). giving appreciation to students who excel with their soft skills, carry out process planning by giving flexibility to students to take part in extracurricular activities such as scouting, literacy, and sports, 5). promoting activities to achieve the output target as written in the motto of the boarding school, i.e: "Healthy Body, Knowledgeable, Free Thinking" and plus the Five Spirits of Modern Islamic Boarding Schools: Sincerity, Simplicity, Self-Reliance, Ukhuwah Islamiyah, and Freedom, 6). Holding out monitoring and embedded mentoring, 7). carrying out the joyous arena as a media or means of meeting the student guardians, alumni, and society members in the frame of the people's entertainment that is served by the students, and 8). actively participating in regional and national scout championships, as well as collaborating with stakeholders.

In implementing stakeholder-based education marketing, MTs Darul Hikmah divides the roles to maximize the achievement of these goals. This was done by dividing the tiered mentoring activities, starting from working groups assisted by 
OPPM (MIBAO), followed by OPPM accompanied by Asatidz councils, which automatically accounted for the institution and the guardian of students of MTs Darul Hikmah. All activities carried out by the working group above are programs that have been planned by the institution together with the committee, so that there are no new programs that change existing and predetermined activities and schedules. If there are new suggestions, these are notes that will later be discussed in an evaluation meeting with the foundation, managers, and the working group in charge of education marketing at MTs Darul Hikmah. Every year, it is almost certain that the Happy Arena event is held, and there is always something new in this people's entertainment week, both in terms of appearance, entertainment management and from the educational side of entertainment. This is an example of an activity that always innovates and is based on the evaluation of each activity. All parties realize that apart from refreshing, the joyous arena is also a stage for introducing educational products both offline and online on the Youtube channel.

The two educational institutions that are the locus of research, especially in the focus of implementing stakeholder-based educational marketing did activities that aim to encourage all group members to carry out planning or so that all groups are willing to work consciously and voluntarily, in order to achieve a goal that has been established. determined, and in accordance with the organizational plan.

Thus, the theory development found by researchers is the implementation of educational marketing by maximizing alumni and strengthening emotional relationships, so that alumni voluntarily sacrifice their energy, thoughts, and assets to raise an institution that was once their campus. An optimistic attitude and deep love, hereinafter referred to as fanaticism, are motivation in itself to attend Sunan Gunung Jati Islamic Junior High School and MTs Darul Hikmah, so it is not surprising that those attending the school are family, relatives, neighbors and those who today are alumni. This fanatical attitude is what researchers call a market fanatic, originated from the ideological market.

\section{Stakeholders-Based Educational Marketing Supervision}

Stakeholder-Based Education Marketing Supervision at Islamic Junior High School of Sunan Gunung Jati, Ngunut, Tulungagung, is carried out on an on-going process or supervision is carried out during the activity by compiling the activity achievement index, monitoring the facts of the field (especially for expedition activities outside Java island), monitoring at any time complete stages, and supervision every year when starting marketing activities in the following year.

Supervision is a systematic effort by first setting standards for achieving goals, the method used to measure the results achieved and the efforts to be made if there is a deviation from the goals that have been set together, as written by Terry (1973) "Controlling is determining what is being accomplished, that evaluating 
performance and if necessary applying corrective measure, so performance takes place according to plans".

A strict supervision is a form of the seriousness of an institution to achieve its goals in understanding effective and efficient performance because in principle, supervision will talk about what is currently and what has been carried out. Supervision of educational marketing management should refer to the plans and targets set. Supervision conducted together, has a tendency to be able to accommodate quick responses to tactical steps. Regular meetings in the framework of exchanging information, evaluating and determining new plans with reference to factual information from various parties and stakeholders are a series of monitoring combined with a follow-up plan from the results of the supervision.

The institution carries out supervision at the end of the activity as an effort to streamline time and cost efficiency as well as check the conformity between the results achieved with previous targets. Thus it can be concluded that the process evaluation serves to maintain the quality of the implementation of activities, while evaluation after the activity ends aims to maintain consistency in the achievement of predetermined targets.The annual evaluation or evaluation held before starting educational marketing activities in the following year is conducted by the institution with the team and new team candidates to read opportunities and identify problems or obstacles that have been faced in previous marketing activities. In other terms, annual evaluation is an effort to maintain the continuity of an idea or ideas and innovation as a new breakthrough.

The second research data obtained by researchers from MTs Darul Hikmah in stakeholder-based education marketing supervision is to carry out systemic, tiered, and layered supervision. It is called systemic supervision because it puts forward the system regardless of whoever runs it and the results are just as good because it is in accordance with the system. Systematic supervision in this research is a flow that is made systemically starting from the Modern Islamic Boarding Association Organization (MIBAO/OPPM) which oversees Teaching and Learning Activities (TLA) to Kuliyyatul Mu'alimin Indonesia (KMI) which runs in the Darul Hikmah Islamic boarding school. MIBAO is monitored by the Asatidz board and the Asatidz is monitored by an institution which is then responsible to the foundation, so that output is truly guaranteed because of the tight, tiered and standardized supervision.

Based on the facts explained earlier, it is not surprising that every year MTs Darul Hikmah always rejects students who register after the target number of students each year is met. This was not because of being arrogant or because of a lack of classrooms for learning but it was done solely because they did not want to disappoint customers who had put their children to be educated at MTs Darul Hikmah.

From the explanation above, the two institutions in conducting supervision are very strict and indeed do not want a technical or process error outside the predetermined planning. This is in accordance with what Terry said: "Controlling is determining what is being accomplished, that evaluating performance and if the 
necessary applying corrective measure, so performance takes place according to plans".Both institutions strive to guard all planning to achieve perfect targets in terms of educational marketing by eliminating errors or "zero defects". This is likely to be realized because it only requires cohesiveness and team communication by drowning the personal ego in order to walk towards a common goal.

\section{CONCLUSION}

The implementation of stakeholder-based education marketing is conducted by: (1) providing encouragement to all stakeholders to be willing to work consciously and voluntarily in order to achieve a predetermined goal in accordance with the plan; (2) conducting placement tests for prospective students as a form of planning consistency; (3) promoting the fulfillment of qualifications and improve teacher professionalism through comparative studies, training and education; (4) completing the fulfillment of facilities and infrastructure and provide opportunities for students to take part in extracurricular activities; (5) targeting outputs that have morality, intelligence, health, achievement, and competitiveness which are realized through a concrete and structured planning, process, evaluation and follow-up scheme; (6) doing routine evaluation as a strategy for realizing the effectiveness of activities and efficiency in financing as well as accelerating the response to achieve the set targets; (7) conducting integration with stakeholders is an effort to bring educational products closer to customers in an effort to achieve customer satisfaction. In terms of implementation, stakeholder-based education marketing carries out its objective activities by providing encouragement to all group members to carry out predetermined plans. Meanwhile, the theory development found by researchers is the implementation of educational marketing by maximizing alumni to strengthen emotional relationships so that alumni voluntarily sacrifice their energy, thoughts, and assets to raise an institution that was once their alma mater. An optimistic attitude and deep love, hereinafter referred to as fanaticism, are motivation in itself to attend Sunan Gunung Jati Islamic Junior High School and MTs Darul Hikmah, so it is not surprising that those attending the school are family, relatives, neighbors and those who today are alumni. This fanatical attitude is what researchers call a market fanatic, originated from the ideological market.

Stakeholder-Based Education Marketing Supervision is carried out by (1) Supervision, which is a systematic effort by starting to determine the standard of achievement of objectives, so that the target of success or failure can be measured; (2) Strict supervision is a manifestation of the seriousness of an institution in achieving institutional goals in terms of understanding effective and efficient performance, because in principle, supervision will talk about what is currently and what has been carried out; (3) Supervision of educational marketing management must refer to the plans and targets set; (4) Supervision that is carried out together, has a tendency to be more able to accommodate quick responses to tactical steps; (5) Regular meetings of 
the parties and stakeholders in the framework of exchanging information, evaluating and determining new plans with reference to factual information from various parties and stakeholders is a series of integrated supervision by combining inherent supervision and follow-up plans. Both institutions strive to guard all planning to achieve perfect targets in terms of educational marketing by eliminating errors or "zero defects". This is likely to be realized because it only requires cohesiveness and team communication by drowning the personal ego in order to walk towards a common goal.

\section{ACKNOWLEDGMENTS}

The implication of the research results on stakeholder-based educational marketing management strengthens Philip Kotler's theory that the essence of marketing management is planning, directing and supervising all educational marketing activities or part of education. Marketing management provides the form of a plan that is carried out to organize marketing to get the desired profit according to a previously planned plan. Marketing management is a way to get as much profit as possible in the marketing process.

\section{REFERENCES}

[1] Alipour, Mehrdad et al. (2012) A new marketing Mix: The tips for private School Marketing in Iran,

[2] Alma, Buchari (2014), Manajemen Pemasaran dan Pemasaran Jasa. Bandung: Alfabeta

[3] Alma, Buchari dan Ratih Hurriyati, (2008), Manajemen Corporate dan Strategi pemasaran jasa Pendidikan Fokus pada Mutu dan Layanan Prima, Bandung: Alfabeta

[4] Asmani, Jamal Ma'ruf (2015), Manajemen Efektif Marketing Sekolah, Yogyakarta: Diva Press.

[5] Freeman, (1984) Strategic Management: A Stakeholders' Approach. Boston: Fitman

[6] Goi, Chai Lee (2009). A Review of Marketing Mix: 4Ps or More?, International Journal of Marketing Studies, Vo. 1 No. 1

[7] Hasyim, Farid (2009), Strategi Madrasah Unggul, Yogyakarta: Prismasophie

[8] Hidayat, Ara dan Imam Machali, (2010) Pengelolaan Pendidikan: Konsep, Prinsip dan Aplikasi dalam Mengelola Sekolah dan Madrasah, Bandung: Pustaka Educa

[9] Kartajaya, Hermawan dan Muhammad Syakir Sula. (2006), Syariah Marketing. Bandung: PT. Mizan Pustaka

[10] Maimun, Agus dan Agus Zaenul Fitri, (2010) Madrasah Unggulan: Lembaga Pendidikan Alternatif di Era Kompetitif, Malang: UIN-MALIKI Press

[11] Manchanda, Puneet (2004), Response Modeling With Nonrandom Marketing-Mix Variables, Journal of Marketing Research Vol. XLI

[12] Moleong, Lexy J, (2006), Metodologi Penelitian Kualitatif, (Bandung: PT. Remaja Rosdakarya

[13] Moloeng, Lexy J. (2004) Metode Penelitian Kualitatif, Bandung: Rosdakarya

[14] Muhaimin, dkk, (2009), Manajemen Pendidikan: Aplikasinya dalam Penyusunan Rencana Pengembangan Sekolah/Madrasah, Jakarta: Kencana.

[15] Muhaimin. (2010), Manajemen Pendidikan. Jakarta: Kencana 
[16] Sugiyono (2006), Metode Penelitian $R$ and $D$ Bandung:Alfabeta Lazaruth, Soewadji, (1994). Kepala Sekolah dan Tanggung Jawabnya, Yogyakarta: Kanisius

[17] Terry. George R. (1973), Principle of Management Illinois: Richard D.Iwin nc,

[18] Ulfatin, Nurul dan Teguh Triwiyanto. (2016), Manajemen Sumber Daya Manusia Bidang Pendidikan. Jakarta: PT. Raja Grafindo

[19] Zubaedi, (2012), Isu-Isu Baru dalam Diskursus Filsafat Pendidikan IslamDan kapita Selekta Pendidikan Islam, Yogyakarta: Pustaka Pelajar 